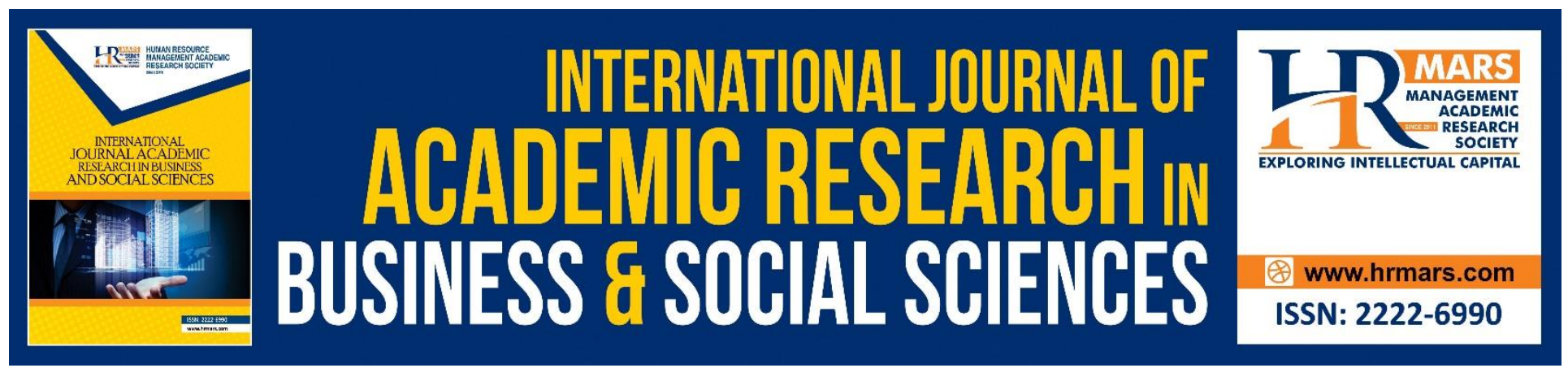

\title{
Does Multifaceted Poverty Approach Enhance the Identification of The Poor and Needy in Zakat Institutions?
}

\section{Azhana Othman}

To Link this Article: http://dx.doi.org/10.6007/IJARBSS/v8-i11/4954

DOI: $10.6007 /$ IJARBSS/v8-i11/4954

Received: 19 Oct 2018, Revised: 07 Nov 2018, Accepted: 29 Nov 2018

Published Online: 07 Dec 2018

In-Text Citation: (Othman, 2018)

To Cite this Article: Othman, A. (2018). Does Multifaceted Poverty Approach Enhance the Identification of The Poor and Needy in Zakat Institutions? International Journal of Academic Research in Business and Social Sciences, 8(11), 779-790.

\section{Copyright: (C) 2018 The Author(s)}

Published by Human Resource Management Academic Research Society (www.hrmars.com)

This article is published under the Creative Commons Attribution (CC BY 4.0) license. Anyone may reproduce, distribute, translate and create derivative works of this article (for both commercial and non-commercial purposes), subject to full attribution to the original publication and authors. The full terms of this license may be seen

at: http://creativecommons.org/licences/by/4.0/legalcode

Vol. 8, No. 11, 2018, Pg. 779 - 790

http://hrmars.com/index.php/pages/detail/IJARBSS

JOURNAL HOMEPAGE

Full Terms \& Conditions of access and use can be found at http://hrmars.com/index.php/pages/detail/publication-ethics 


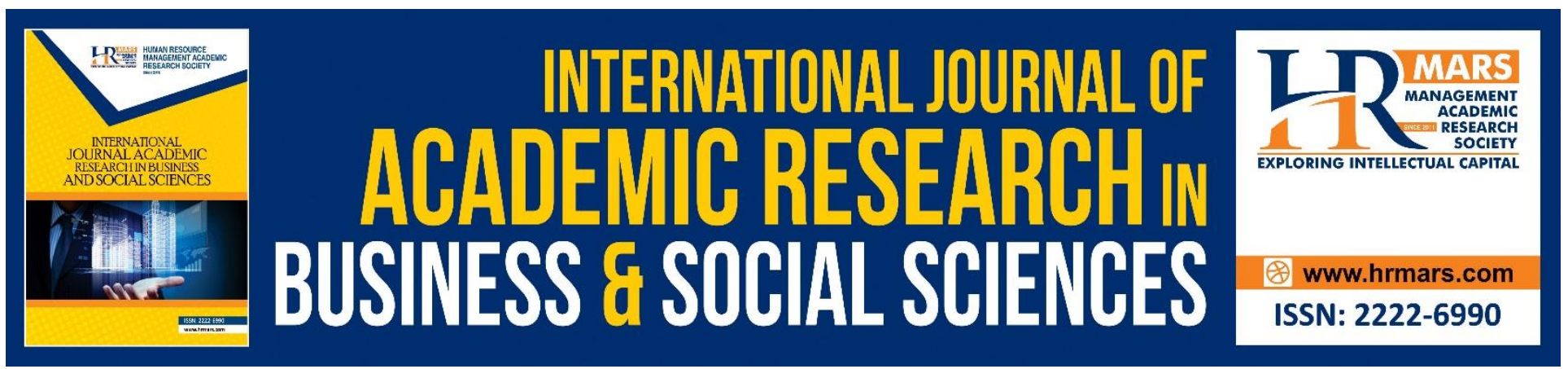

\title{
Does Multifaceted Poverty Approach Enhance the Identification of The Poor and Needy in Zakat Institutions?
}

\author{
Azhana Othman \\ Centre for Islamic Philanthrophy and Social Finance (CIPSF), Universiti Teknologi MARA \\ Malaysia
}

\begin{abstract}
Poverty is frequently associated with the lack of monetary resources in fulfilling one's need. However, current developments indicate that there are other aspects that are equally important in addressing the issues of poverty. Thus, accurate diagnosis of the causes of poverty and the identification of the poor and the needy is crucial in ensuring proper assistance is extended to those who are in need. There are two main approaches in identifying poverty namely objective and subjective poverty. Objective poverty is based on income while subjective poverty utilised a participatory approach in determining poverty status. This study further includes zakat (tithe) based poverty associated with zakat institutions, as it is the focus of this study. Zakat based poverty or had-al-kifayah considers expenditure of household in determining the minimum amount requires by household. Zakat institutions are organisations entrusted to collect and distribute zakat to the beneficiaries; utilised zakat-based poverty line to screen applicants for zakat fund distribution. Zakat based poverty line income is a variant of objective poverty. However, the multifaced nature of poverty should include subjective poverty approach for a more accurate identification of the poor and the needy. As such, the paper evaluates the three poverty approaches as discussed. Data were obtained from a survey of the applicants of zakat fund in the State Islamic Religious Council (SIRC) of Melaka, one of the states in Malaysia. Our findings revealed that there are significant differences between each approach in determining who the poor are. Poverty Line Income and zakat-based poverty reported a lower number of poor and needy compare to subjective poverty estimates. Subjective poverty approach if utilised will complement current approaches and enhance the identification of the poor and need. Keywords: Subjective poverty, Objective poverty, Poverty line income, Zakat, Zakat based poverty line
\end{abstract}


INTERNATIONAL JOURNAL OF ACADEMIC RESEARCH IN BUSINESS AND SOCIAL SCIENCES

Vol. 8, No. 11, Nov, 2018, E-ISSN: 2222-6990 @ 2018 HRMARS

\section{Introduction}

Poverty is a widely used and meaningful concept in all countries in the world. Poverty has become an economic, social, and political issue all over the world particularly in the developing and third-world nations including many of the Muslim countries. Although poverty is a universal concept, its definition is often contested. In general, it is believed that governments and markets alone are unlikely to solve the poverty problem. Therefore, it is crucial for other parties consisting of the general societies, nonprofits and non-government organizations to actively participate in encouraging economic growth and welfare, thus alleviating poverty.

In Islam, poverty is defined based on an individual failure to fulfil any of the five basic human requirements of life that is based on Maqasid Syariah: 1) religion, ii) physical self, iii) knowledge, iv) dignity, and v) wealth (Ahmad Nadzri, Abd Rahman, \& Omar, 2012). Consistent with the brotherhood concept in Islam, Muslims were strongly encouraged to look after the poor in their community.

Generally, poverty is measured in monetary terms, based on the income levels or consumption per capita or per household. On the other hand, Islam defines poverty based on individual failure to fulfil any of the five basic human requirements of life that is based on Maqasid Syariah. In Islam, poverty were views as social and ideological problems. It is considered as social problem due to the effect are felt in the society as a whole. Moreover, it is also an ideological problem as it affects the performance of one's socio-religious obligation towards the community and Islam. Therefore, it was suggested that poverty cannot be alleviated through income redistribution only, but it needs to include a holistic approach.

Zakat is one of the five pillars of Islam where wealth is transferred from the wealthy to the needy. Zakat is carried out by formal zakat institutions, and sometimes it is distributed directly by the zakat payers to the asnaf or recipients of the zakat. In Malaysia there are 14 zakat institutions under the religious department of various states. In principle, the main role of zakat institutions is to distribute wealth from zakat payers to the asnaf. Asnaf comprises the poor, destitute (needy), amil (zakat collector), muallaf (newly converted Muslim), al-gharimin, fi sabilillah (striving in the path of Allah), ar-riqab (slave) and ibn-sabil (needy traveller) (Mohd Ali, Abd. Rashid, Johari, \& Ab. Aziz, 2015). Although these eight types of people have been mentioned in the Qur'an, but the first priority in the use of Zakat funds has to be accorded to the alleviation of poverty through assistance to the poor and the needy (Mohd Ali \& Ab. Aziz, 2014). One important issue that needs to be addressed by zakat institutions is the ability of zakat funds in reaching the intended asnaf besides providing confidence to the Muslim society that the zakat is fairly distributed. One key factor in achieving this is the process of identifying the rightful asnaf especially the poor and destitute. This is due to the possibility of fraud in distributing zakat is greater importance than determine the source and collection of zakat (Mohd Noor, Che Man, \& Ibrahim, 2015). This view clearly shows the distribution of zakat is a great trust and a huge responsibility borne by the zakat institutions. In discharging its responsibility to distribute zakat effectively, then prioritizing the asnaf is important (Mohd Noor, Che Man, \& Ibrahim, 2015). Thus, the objective of this paper is to examine whether multifaceted poverty approaches enhance the identification of the poor and needy in zakat institutions. This paper is organized as follows. The next section outlines the literature review whereas the methodology undertaken in this study is 
INTERNATIONAL JOURNAL OF ACADEMIC RESEARCH IN BUSINESS AND SOCIAL SCIENCES Vol. 8, No. 11, Nov, 2018, E-ISSN: 2222-6990 @ 2018 HRMARS

deliberated in the following sections. Next section is on the findings of the study. Finally, the conclusions of the study are highlighted in the last section.

\section{Approaches to Poverty Measurement}

There are two main approaches in measuring poverty namely objective poverty and subjective poverty. A different approach makes the distinction between the perspective through which poverty is measured: objective or subjective. Objective based poverty utilised monetary or income level in determining poverty while subjective poverty further includes other intangible aspects such as capability, health, accessibility, among others. Subjective poverty propagates a participatory approach. This section discusses both types of poverty determination approaches. It also includes zakat-based poverty which is a variant of objective poverty. It includes expenditure of household in determining who are poor.

\section{Poverty Line Income (PLI)}

The income or monetary approach takes into account the monetary needed to acquire the goods and services that satisfy given standards of living (that could be absolute or relative to the society where individuals live (Rowntree,2000). Poverty Line Income (PLI) is set by the Economic Planning Unit (EPU) of the Prime Minister Department (Abdul Rasool, Mohd Harun, Mohd Salleh, \& Idris, 2011). The PLI is the level of income that is just sufficient to obtain the minimum necessities of life or basic needs which includes both food and non-food items (Mat Zin, 2007). A person/household is considered poor if his or her income falls below that line. Malaysia developed its own poverty line in the 1970s when the government's national policy gave a high priority for poverty eradication and the government utilized this poverty line on assessment of the minimum consumption requirements of an average sized household for food, shelter, clothing and other non-food needs (Hatta \& Ali, 2013).

Poverty in Malaysia is commonly conceptualized and operationalized by the monetary approach through conventional Poverty Line Income (PLI). Economists have argued that the current poverty measures are not able to reflect the multidimensional nature of poverty which has developed due to the rapid economic development process and changes in the economic structure. Malaysia government even had revised the method of calculating poverty line for Ninth Malaysian Plan 20062010 (Ragayah, 2007). The approach of specifying poverty line is known as absolute approach in measuring poverty. The relative approach also used the poverty line as a comparison to the average standard of living of a particular society at a particular time.

Malaysia is no longer just grappling with absolute poverty but also with relative poverty, pockets of persistent poverty and urban poverty as well as increasing inequalities (Nair,2010). This is clearly exemplified in the recently launched New Economic Model (NEM) which provides the policy framework for Malaysia to move from a middle income to a high-income nation by 2020 . Therefore, poverty in Malaysia can no longer be addressed in the same way as it has been done in the past.

\section{Zakat Poverty Line (ZPL) or Had-Al-Kifayah}

Zakat Poverty Line (ZPL) is a measure of the level of economic sufficiency of a person that enables him to live a normal life. In the context of zakat, Zakat Poverty Line is the separating line between 
INTERNATIONAL JOURNAL OF ACADEMIC RESEARCH IN BUSINESS AND SOCIAL SCIENCES Vol. 8, No. 11, Nov, 2018, E-ISSN: 2222-6990 @ 2018 HRMARS

those who need to pay zakat (muzakki) and those who are entitled to zakat (asnaf) (Ab Rahman \& Tengku Zainal Abidin, 2017).

Zakat Poverty Line refers to a minimum base rate requirement set based on the current cost of living (JAWHAR, 2009) by zakat institutions. Zakat Poverty Line is also used to determine the rate to be assisted to meet the adequacy of fund expenditures (Zakat State Distribution Module Center). For those who have income above Zakat Poverty Line are among the rich and not eligible to receive zakat. The practice of setting limits for states in Malaysia is done by looking at income and expenditure ratios. Household income earning below $50 \%$ of Zakat Poverty Line value will be categorized as poor and household income earning between $50 \%-100 \%$ will be categorized as poor. Household income above the Zakat Poverty Line is not categorized as poor (Sayin Bhari, 2017)

Referring to the Table 1, the example considered a family of 6 family members with both working parents, an adult aged 18-year-old and above who are still studying at a higher educational institution, a teenager aged between 13 to 17 years old, a school-age child 7 to 12 -year-old and a child in the age group 0 to 6 years living in the urban area. The ZPL for urban area, Johor (RM 1,745), Kedah (RM960), Melaka (RM 1,440), Perak (RM 1,655), Sabah (RM 1,850) and Selangor (RM 2,040). While for rural area, only Johor, Perak, Sabah and Selangor had slightly different value for ZPL (Sayin, Mat Rani, \& Bhari, 2016).

Table 1: Zakat Poverty Line for Urban and Rural area in Malaysia.

\begin{tabular}{|l|l|l|l|}
\hline Bil & Negeri & Urban (RM) & Rural (RM) \\
\hline 1 & Johor & $1,745.00$ & $1,645.00$ \\
\hline 2 & Kedah & $960.00(\mathrm{~b}) / 815.00(\mathrm{p})$ & $960.00(\mathrm{~b}) / 815.00(\mathrm{p})$ \\
\hline 3 & Melaka & $1,440.00$ & $1,440.00$ \\
\hline 4 & Perak & $1,655.00(\mathrm{~b}) / 1,403.00(\mathrm{p})$ & $1,157.00(\mathrm{~b}) / 959.00(\mathrm{p})$ \\
\hline 5 & Pulau Pinang & $1,110.00(\mathrm{~b}) / 950.00(\mathrm{p})$ & $1,110.00(\mathrm{~b}) / 950.00(\mathrm{p})$ \\
\hline 6 & Sabah & $1,850.00$ & $1,455.00$ \\
\hline 7 & Selangor & $2,040.00(\mathrm{~b}) / 1,715.00(\mathrm{p})$ & $1,640.00(\mathrm{~b}) / 1,440.00(\mathrm{p})$ \\
\hline 8 & Wilayah Persekutuan & $2,470.00(\mathrm{~b}) / 2,020.00(\mathrm{p})$ & $2,470.00(\mathrm{~b}) / 2,020.00(\mathrm{p})$ \\
\hline
\end{tabular}

Zakat Poverty Line is determined by the respective zakat institutions, basically its determines the level of necessity needed by a household to sustain daily needs (Abdul Rasool et.al, 2013; Mohd Ali et.al, 2014). It is calculated based on various variables such as the number of members in a household, age group of members etc. JAWHAR (2007) has outlined the main components in determining Zakat Poverty Line (necessity) of a household as shelter, food, clothing, health, education and transformation based on maqasid al sharia (human needs). However, it is up to each zakat institutions to decide on the details of each of these components. Different states have different ZPL or had-al-kifayah based on different variables used and prices would be differing according to location and area (Mohd Ali \& Ab. Aziz, 2014). It is important to note that Zakat Poverty Line in a state varies from one household to another depending on the number of household members and age group in the household. 
INTERNATIONAL JOURNAL OF ACADEMIC RESEARCH IN BUSINESS AND SOCIAL SCIENCES Vol. 8, No. 11, Nov, 2018, E-ISSN: 2222-6990 @ 2018 HRMARS

Table 2: Zakat Poverty Line for 11 States in Malaysia

\begin{tabular}{|l|l|l|l|l|l|l|l|}
\hline Bil & State & House & Food & Transportation & Education & Cloths & Health \\
\hline 1 & Johor & 400 & 800 & 165 & 190 & 170 & 60 \\
\hline 2 & Kedah & 180 & 285 & 165 & 90 & 80 & 90 \\
\hline 3 & Kelantan & 312 & 337.40 & 390 & 180 & 180 & 179.60 \\
\hline 4 & Melaka & - & - & - & - & - & - \\
\hline 5 & N. Sembilan & 390 & 480 & 185 & 150 & 156 & 103 \\
\hline 6 & Perak & 312 & 337.40 & 390 & 180 & 180 & 179.60 \\
\hline 7 & $\begin{array}{l}\text { Pulau } \\
\text { Pinang }\end{array}$ & 200 & 330 & 180 & 150 & 80 & 85 \\
\hline 8 & Sabah & 350 & 590 & 290 & 155 & 240 & 165 \\
\hline 9 & Selangor & 480 & 750 & 400 & 120 & 210 & 60 \\
\hline 10 & Terengganu & 360 & 1,160 & 620 & 230 & 170 & 60 \\
\hline 11 & $\begin{array}{l}\text { Wilayah } \\
\text { Persekutuan }\end{array}$ & 550 & 810 & 380 & 130 & 210 & 210 \\
\hline
\end{tabular}

Household income in the form of Ringgit Malaysia is a key indicator in determining the limits of kifayah adopted by the Center for Zakat of States (Sayin \& Bhari, 2017). However, there is inconsistency in the level of kifayah limits between states. The differences recorded in the rates of the state's fees were due to the different cost of living mainly in the cost of ownership of the residential property and the designated rental value, the cost of food, clothing, transportation, education, and health. Differences also occur between urban and rural areas in the same state (Sayin, Mat Rani, \& Bhari, 2016).

To date, there is no guideline that is mutually agreed by each institution of zakat in Malaysia in determining the estimate of the Zakat Poverty Line (Ab Rahman \& Tengku Zainal Abidin, 2017). However, both PLI and ZPL are objective measures. Thus, this study aims to include the subjective poverty measure in understanding the poverty.

\section{Subjective Poverty (SP)}

Subjective poverty involved the poor self-assessment on whether they are poor based on their wellbeing evaluation. Subjective measure is likely influenced by different aspects of individual's life such as access to services, access to land, health, income, employment and basic needs (Rio Group, 2006). Subjective poverty is defined as an individual feeling and not an objective status. Thus, an individual may be physically poor but as he/she has higher satisfaction or higher well-being. Subjective poverty reflects the cognitive evaluation of one's life and is therefore to be regarded as the broadest concept, since it is not restricted to just one dimensions (income or expenditure-as in the monetary approach) or several dimensions (like health, education and income-as in the capability approach) but is open to all the dimensions the individuals is incorporating for its evaluation (Neff, 2007).

Two definitions of subjective poverty were summarized as firstly, it involves an individual assessment of their poverty status and secondly, by setting the subjective poverty line on what they deliberate to be the crucial minimum income to achieve minimum basic needs (Santarelli, 2013). 
Although, there are abundance researches on absolute poverty, the research on determinants of either relative of subjective poverty in developing countries is still dearth (Dartanto \& Otsubo, 2012). Researchers such as Goedhart, Halberstadt, Kapteyn \& Van Praag (1977); Van Praag, Goedhart \& Kapteyn (1980); Van Praag and Ferrer-i-Carbonell (2005) agreed that the aspects of poverty are not exclusively on objective measures, that is level of income but also depends on people's perceptions and feelings on their well-being. In this term, meanings that the poor own assessment are important to help better understandings of their needs.

\section{Multifaceted Poverty}

Poverty is also a multifaceted phenomenon where different societies have different perceptions of poverty. It varies across countries with different socio-economic norms. It may also change over time even in the same society, with different stages of social and economic development.

Some of the studies compared the objective and subjective indicators in measuring poverty. For example, a study on multifaceted poverty in Indonesia using five poverty indicators which are absolute, relative, subjective well-being (SWB) and subjective poverty measure. Meanwhile another study in South Africa, measure poverty using absolute income poverty, relative income poverty, subjective income poverty, subjective poverty and subjective well-being method.

As economist argued that the current poverty measuring using monetary indicators or objective approach is not able to reflect the nature of poverty (Nair,2000). Thus, there is a need to look at multifaceted nature of poverty by taking account the non-monetary indicators or subjective approach.

\section{Data and Methodology}

Data for the study are gathered through a formal survey using a structured questionnaire. The survey done in March-April 2016 involved of 507 zakat applicants from Melaka.

In this study, two notion of poverty measurement were analysed. The first one is objective poverty measures, consist of Poverty Line Income (PLI) and Zakat Poverty Line (ZPL) or Haddul kifayah. While, the subjective poverty measures involved of Subjective Poverty Index (SPI).

Figure 1: Multifaceted Poverty Measurement

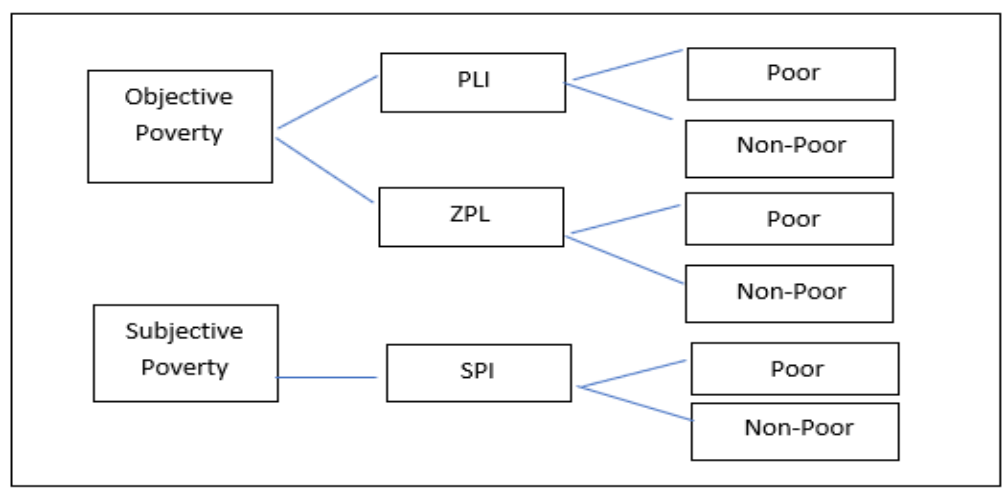


1) Poverty Line Income (PLI)

The PLI is determined by Economic Planning Unit. The PLI for Melaka in 2016 is RM960. Therefore, if the household's income is below RM960, the household is poor and if their income is above RM 960, they are considered as non-poor.

2) Zakat Poverty Line (ZPL) or Had-al-kifayah

The ZPL or Had-al-kifayah is determine by SIRC of Melaka in identifying whether the zakat applicants are poor or non-poor. If they are poor, their zakat application will be accepted. On the other hand, if they are non-poor, their zakat application will be rejected.

Had al kifayah is used to determine the level of necessities needed by a household to sustain daily needs. Had al kifayah is calculated based on various variables such as number of members of a household, members age group, etc. To determine the category of the household whether they are poor or not is based on the following calculation: Excess income $=$ Total Income - Total Expenditure on necessities of a household.

Faqir (needy) is defined as a person who does not have any halal or income or income receipts is not up to $50 \%$ of the daily basic needs of the person and their dependence on a moderate measure of living. Asnaf Miskin (poor) is a person who has property or income that exceeds $50 \%$ but does not reach the limit of kifayah for his or her basic needs and dependents.

3) Subjective Poverty Line Index

The SPI calculated based on weighted index of subjective poverty determinants. Intensity of subjective poverty deprivation is negligible if household score is less than 20. Moderate subjective poverty deprived if household score is between 20 and 50. High subjective poverty deprived if household score is $>50$ but less than 75 . Very high subjective poverty deprived if the household score is $>75$. Thus, in this analysis, the score below 50 is considered as non-poor and the score above 50 considered as poor.

The multifaceted poverty analysis is presented in three analyses: 1) frequency, 2) crosstabulation and 3) Kruskal -Wallis Test.

\section{Findings And Discussion}

1) Frequency

Table 3: Number of poor and non-poor based on poverty line income (PLI)

\begin{tabular}{|l|l|l|l|l|}
\hline Status & Frequency & Percent & $\begin{array}{l}\text { Valid } \\
\text { Percent }\end{array}$ & $\begin{array}{l}\text { Cumulative } \\
\text { Percent }\end{array}$ \\
\hline $\begin{array}{l}\text {.00 (non-poor) } \\
1.00 \text { (poor) }\end{array}$ & 247 & 48.7 & 48.7 & 48.7 \\
Total & 507 & 51.3 & 51.3 & 100.0 \\
\hline
\end{tabular}

Table 3 shows the demographic profile of respondents with the total of 507 based on poverty line income (PLI). Firstly, there were 247 respondents of non-poor scoring $48.7 \%$ and the remaining 260 respondents were from poor scoring $51.3 \%$. There was a very slight difference between non-poor and poor respondents which poorer who took part in this study compared to poor based on poverty line income (PLI). 
INTERNATIONAL JOURNAL OF ACADEMIC RESEARCH IN BUSINESS AND SOCIAL SCIENCES Vol. 8, No. 11, Nov, 2018, E-ISSN: 2222-6990 (C) 2018 HRMARS

Table 4: Number of poor and non-poor based on zakat line income (ZPL)

\begin{tabular}{|l|l|l|l|l|}
\hline Status & Frequency & Percent & $\begin{array}{l}\text { Valid } \\
\text { Percent }\end{array}$ & $\begin{array}{l}\text { Cumulative } \\
\text { Percent }\end{array}$ \\
\hline .00 (non-poor) & 159 & 31.4 & 31.4 & 31.4 \\
1.00 (poor) & 348 & 68.6 & 68.6 & 100.0 \\
Total & 507 & 100.0 & 100.0 & \\
\hline
\end{tabular}

Next, refer table 4 the number of poor and non-poor respondents has presented based on Zakat Line Income (ZPL). It has recorded that there were 159 (31.4\%) non-poor respondents and there were 348 $(68.6 \%)$ of poor respondents respectively. It has established that poor is the majority respond compared to non-poor based on Zakat Line Income (ZPL) contributed in this study.

Table 5: Number of poor and non-poor based on subjective poverty index (SPI)

\begin{tabular}{|l|l|l|l|l|}
\hline Status & Frequency & Percent & Valid Percent & $\begin{array}{l}\text { Cumulative } \\
\text { Percent }\end{array}$ \\
\hline .00 (non-poor) & 121 & 23.9 & 23.9 & 23.9 \\
1.00 (poor) & 386 & 76.1 & 76.1 & 100.0 \\
Total & 507 & 100.0 & 100.0 & \\
\hline
\end{tabular}

Furthermore, on the other hand, the result has indicated to number of poor and non-poor based on Subjective Poverty Index (SPI), it had shown that there were 121 (23.9\%) respondents enrolled in non-poor whereas there were 386 (76.1\%) respondents enrolled in poor based on Subjective Poverty Index (SPI).

ii) Cross Tabulation

Table 6: Cross Tabulation between Each Poverty Indicators

\begin{tabular}{|c|c|c|c|c|c|c|c|}
\hline \multicolumn{2}{|c|}{ Poverty Measures } & \multicolumn{2}{|l|}{ PLI } & \multicolumn{2}{|l|}{ SP } & \multicolumn{2}{|l|}{ ZPL } \\
\hline PLI & Non-Poor & $\begin{array}{l}\text { Non- } \\
\text { Poor } \\
247 \\
48.7 \\
\end{array}$ & Poor & $\begin{array}{l}\text { Non- } \\
\text { Poor }\end{array}$ & Poor & Non-Poor & Poor \\
\hline & Poor & & $\begin{array}{l}260 \\
51.3\end{array}$ & & & & \\
\hline \multirow[t]{2}{*}{ SP } & Non-Poor & $\begin{array}{l}84 \\
69.4\end{array}$ & $\begin{array}{l}37 \\
30.6\end{array}$ & $\begin{array}{l}121 \\
23.9\end{array}$ & & & \\
\hline & Poor & $\begin{array}{l}123 \\
31.9\end{array}$ & $\begin{array}{l}263 \\
68.1\end{array}$ & & $\begin{array}{l}386 \\
76.1\end{array}$ & & \\
\hline \multirow[t]{2}{*}{ ZPL } & Non-Poor & $\begin{array}{l}70 \\
13.8\end{array}$ & $\begin{array}{l}89 \\
17.5\end{array}$ & $\begin{array}{l}44 \\
36.4\end{array}$ & $\begin{array}{l}115 \\
29.8\end{array}$ & $\begin{array}{l}159 \\
31.4\end{array}$ & \\
\hline & Poor & $\begin{array}{l}137 \\
27\end{array}$ & $\begin{array}{l}211 \\
41.7\end{array}$ & $\begin{array}{l}77 \\
63.6\end{array}$ & $\begin{array}{l}271 \\
70.2\end{array}$ & & $\begin{array}{l}348 \\
68.5\end{array}$ \\
\hline
\end{tabular}


Note: For each cell, the first row contains the number of households in that category. The numbers in the second-row show percentage share in total sample households.

The table above presents a cross tabulation of 507 household being classified as poor or non-poor in each one of the three operationalized poverty definitions. While $48.7 \%$ of households are categorized as PLI non-poor (i.e., $51.3 \%$ as poor), only $23.9 \%$ of household are reported SP non- poor (i.e., $76.1 \%$ as poor). For ZPL, $31.4 \%$ reported as non-poor and another $68.5 \%$ as poor.

While $31.9 \%(123 / 247)$ of households that PLI non-poor reported themselves as SP poor, $30.6 \%$ (37/260) of the PLI poor reported as non-poor in SP judgment category. This evidence indicates that some household that are non-poor in an objective measurement may still feel poor subjectively. In the same token, other household that are poor in an objective metric could still perceive themselves non-poor in subjective metric.

Figure 2: Cross tabulation summary.

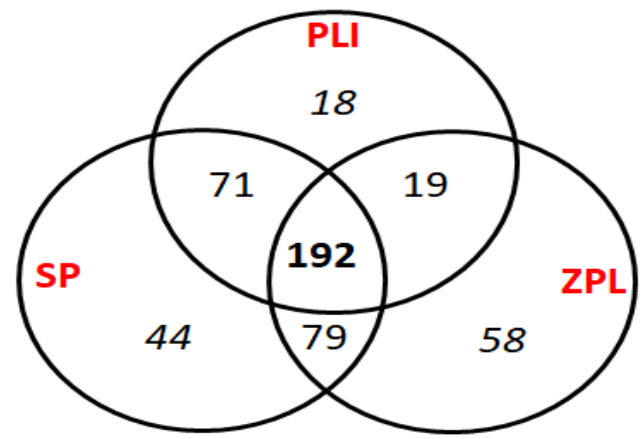

Figure 2 shows that, 192 out of 481 respondents decided that they are identify as poor under all measurements, which are PLI, ZPL and SP. SP measurement identify poorer and needier (386 of respondents), but 95 of respondents were not considered as poor through this measurement. The results found that, although 211 of respondents are poor under objective measure (PLI/ZPL) but, they did not consider themselves as poor.

iii) Kruskal Wallis Test

Kruskal-Wallis test is a rank-based nonparametric test that can be used to determine if there are statistically significant differences between two or more groups of an independent variable on a continuous or ordinal dependent variable. It is considered the nonparametric alternative to the oneway ANOVA, and an extension of the Mann-Whitney $U$ test to allow the comparison of more than two independent groups. 
INTERNATIONAL JOURNAL OF ACADEMIC RESEARCH IN BUSINESS AND SOCIAL SCIENCES

Vol. 8, No. 11, Nov, 2018, E-ISSN: 2222-6990 @ 2018 HRMARS

Table 7: Ranks

\begin{tabular}{llll}
\hline & Approach & $\mathbf{N}$ & Mean Rank \\
\hline Income & .00 & 26 & 337.75 \\
& 1.00 & 120 & 278.60 \\
& 2.00 & 169 & 256.00 \\
& 3.00 & 192 & 225.52 \\
& Total & 507 & \\
\hline
\end{tabular}

Table 8: Test Statistic

\begin{tabular}{ll}
\hline & Income \\
\hline Chi-Square & 45.357 \\
Df & 3 \\
Asymp. Sig. & .000 \\
\hline
\end{tabular}

From the Kruskal-Wallis $\mathrm{H}$ test output, there was a statistically significant difference in the income between different measurement approaches, $X^{2}(2)=45.357, p=.000$, with mean rank income score of 337.75 for PLI, 278.60 for ZPL, 256.00 for SPI and 225.52 for the three approach.

\section{Conclusions}

Poverty is frequently associated with the lack of monetary resources in fulfilling one's need. However, current developments indicate that there are other aspects that are equally important in addressing the issues of poverty. Thus, accurate diagnosis of the causes of poverty and the identification of the poor and the needy is crucial in ensuring proper assistance is extended to those who are in need. There are two main approaches in identifying poverty namely objective and subjective poverty. As economist argued that the current poverty measuring using monetary indicators or objective approach is not able to reflect the nature of poverty (Nair,2000). Thus, there is a need to look at multifaceted nature of poverty by taking account the non-monetary indicators or subjective approach.

The findings indicate that, based on the cross-tabulation test, some household that are non-poor in an objective measurement may still feel poor subjectively. In the same token, other household that are poor in an objective metric could still perceive themselves non-poor in subjective metric and based on Kruskal Wallis test, there was a statistically significant difference in the income between different measurement approaches. Thus, it can be concluded the subjective poverty measures complement in identifying poor and needy.

\section{Acknowledgement}

The authors would like to acknowledge the grant provided by the Accounting Research Institute and Universiti Teknologi MARA Malaysia for this study. Grant reference No: 600-RMI/FRGS 5/3 (48/2016). 
INTERNATIONAL JOURNAL OF ACADEMIC RESEARCH IN BUSINESS AND SOCIAL SCIENCES

Vol. 8, No. 11, Nov, 2018, E-ISSN: 2222-6990 @ 2018 HRMARS

\section{Corresponding Author}

Azhana Othman

Fellow of Centre for Islamic Philanthrophy and Social Finance (CIPSF)

Universiti Teknologi MARA

Kampus Bandaraya Melaka

75350 Melaka

Malaysia

Email: azhana395@melaka.uitm.edu.my

\section{References}

Ab Rahman, A., \& Tengku Zainal Abidin, T. (2017). Strata Had Kifayah Zakat di Malaysia Menurut Maqasid Syariah. In D. Sharif, R. Nordin, \& N. Rabu, Filantrofi: Memperkasa Kewangan Sosial Islam (pp. 179-187). Selangor: USIM.

Abdul Rasool, M., Mohd Harun, M., Mohd Salleh, A., \& Idris, N. (2011). Poverty Measurement in Malaysian Zakat Institutions: A Theoretical Survey. Jurnal Ekonomi Malaysia, 123-129.

Ahmad Nadzri, F., Abd Rahman, R., \& Omar, N. (2012). Zakat and Poverty Alleviation: Roles of Zakat Institutions in Malaysia. International Journal of Arts and Commerce, 61-72.

Hatta, Z. A., \& Ali, I. (2013). Poverty Reduction Policies in Malaysia: Trends, Strategies and Challenges. Asian Culture and History, 48-56.

Mat Zin, R. (2007). Understanding the Formulation of the Revised Poverty Line in Malaysia. Akademika, 21-39.

Mohd Ali, A., \& Ab. Aziz, M. (2014). Zakat Poverty Line Index and Gender Poverty in Malaysia: Some Issues and Practices. International Journal of Business and Social Science, 286-293.

Mohd Ali, A., Abd. Rashid, Z., Johari, F., \& Ab. Aziz, M. (2015). The Effectiveness of Zakat in Reducing Poverty Incident: An Analysis in Kelantan, Malaysia. Asian Social Science, 355-367.

Mohd Noor, A., Che Man, N., \& Ibrahim, S. (2015). International Zakat Distribution. In A. Mohd Noor, \& M. Abdul Rasool, Fiqh Zakat: Addressing Fiqh Zakat Issues in The Contemporary World (pp. 1-12). Kuala Lumpur: Institut Kajian Zakat Malaysia (IKaZ).

Neff, D. F. (2007). Subjective Well-Being, Poverty and Ethnicity in South Africa: Insight from Exploratory Analysis. Social Indicators Research, 313-341.

Santarelli, E. (2013). A Review of The Literature on Subjective Poverty in Europe: A Focus on Data Sources. Roma: Sapienza Universita Di Roma.

Sayin, B., \& Bhari, A. (2017). Penetapan Had Kifayah Zakat Pelajar di UiTM: Satu Keperluan. In M. P. Rameli, D. Sharif, \& N. Che Man, Isu-Isu Kontemporari dalam Pengurusan Ekonomi dan Kewangan Islam (pp. 201-212). Shah Alam: UiTM Press.

Sayin, B., Mat Rani, M., \& Bhari, A. (2016). Kajian Semula Had Kifayah di Malaysia: Satu Penemuan Awal. In A. Mohd Noor, Strenghening Zakat and Waqf Governance. Jakarta: IMZ Publishing. 